\title{
ROSEMARY VOLATILE OIL AS A PRESERVATIVE AGENT IN SOME
} \section{CANNED MEAT FOODS}

\author{
I. J. Abed ${ }^{1}$ \\ Assist. Prof. \\ M. E. Ahmed ${ }^{1}$ \\ Lecturer \\ S. MH AL-Shimmary ${ }^{2}$ \\ ${ }^{1}$ Depart. of Biol. Coll. of Sci, University of Baghdad. \\ ${ }^{2}$ Depart. Biol. Coll. Sci. for Women, University of Baghdad \\ *Corresponds author e-mail: ibrahimabed95@yahoo.com
}

\section{ABSTRACT}

This research was aimed to evaluate activity of Rosemary volatile oil and Nisin $A$ in vivo and on $B$. cereus isolated from some canned meat products in vitro. The results showed that the activity of Rosemary volatile oil $(2000 \mu \mathrm{g} / \mathrm{ml})$ and Nisin A $(350 \mu \mathrm{g} \backslash \mathrm{ml})$ attained to 27 and $19 \mathrm{~mm}$ inhibitory zone diameter respectively in well diffusion method. The viable plate count from samples of canned meat treated with effective concentration of Rosemary volatile oil and Nisin A were examined. The samples with Rosemary volatile oil was not showed any CFU/g after 9 days of preservation while sample with Nisin A and control observed 49 and 45 CFU/g respectively. In vivo experiment on mice, two weeks after oral dose of Rosemary volatile oil $(2000 \mu \mathrm{g} / \mathrm{ml})$ and Nisin A $(350 \mathrm{IU} / \mathrm{ml})$, there were no death. Furthermore, there were no changes in histological sections taken from liver and spleen of mice treated with Rosemary volatile oil while Nisin A have shown changes in liver and spleen weights and gross or histological characteristics. In conclusion, the Rosemary volatile oil have higher antibacterial effect against B. cereus compare with using Nisin A which caused more damage to the organs in the liver and spleen, Thus, it can use the volatile oil of this plant as a preservative at the same time for preservation of meat.

Key words: Bacillus cereus, meat products, $16 \mathrm{~S}$ rRNA, Nisin A and B

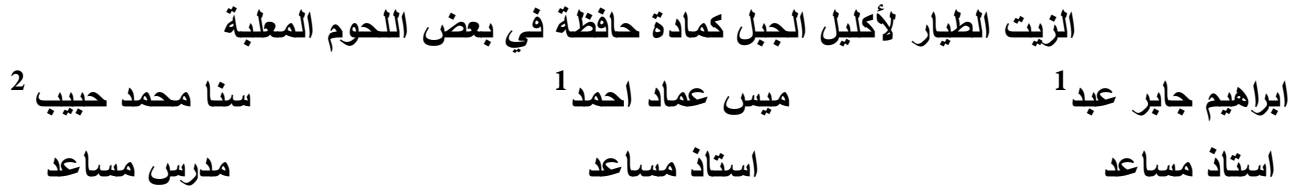

$$
\text { 2قسم علم علوم الحياة- كلية العلوم، جامعة بغداد، العرلق الحياة- كلية العلوم للبنات، جامعة بغداد، العراق }
$$

B. cereus و الزيت الطيار لأكليل الجبل في الجسم الحي لفئران التجارب على بكتريا

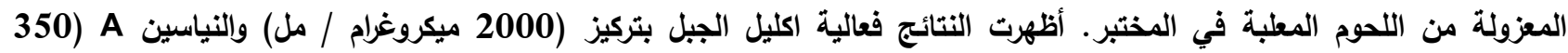

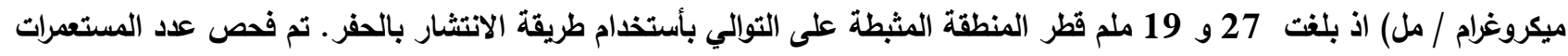

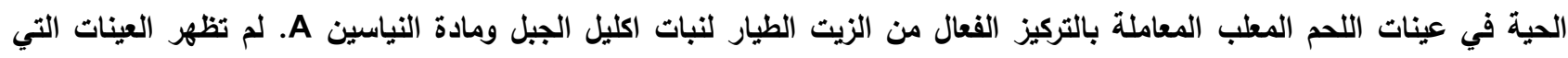
تحتوي على الزيت الطيار لنبات اكليل الجبل على أي مستعمرة بكتيرية حية في اللحوم بعد 9 أيام من الحفظ بينما لوحظ ان العينة المعاملة بمادة النياسين A والسيطرة كان تعداد المستعمرات الحية فيها 45 و 49 على التوالي. في التجرية المختبرية التي أجريت على التئئ الفئران،

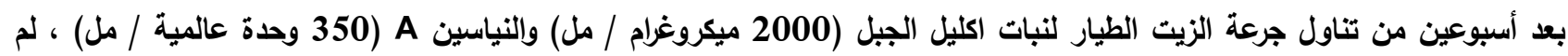

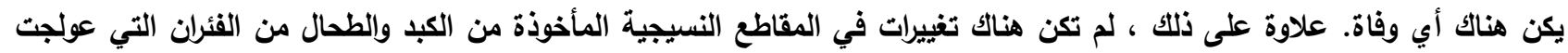

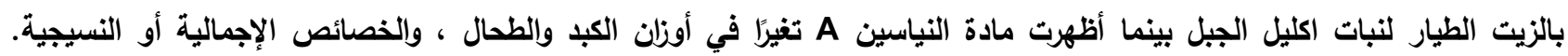

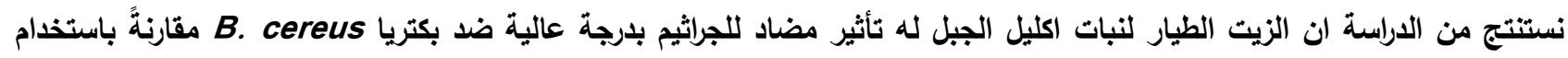
مادة النياسين A والذي تسبب في حدوث أضرار أكبر للأعضاء في الكبل والطحال مما يرجح من استخدام الزيوت الطيارة لهذا النبات كمادة حافظة لحفظ اللحوم. الكلمات المفتاحية: B. cereus, منتجات اللحوم, 16 الرنا الرايبوسي,النياسين, الزيت الطيار , النياسين اي 


\section{INTRODUCTION}

Bacillus cereus causes two distinct food poisoning syndromes, characterized, respectively, by emesis and diarrhea. It is most common of which is a highly fulminant posttraumatic endophthalmitis (30 The great majority of research on the pathogenic nature of this organism has been toward identifying and characterizing a diarrheal enterotoxin. The toxin or toxins involved in the diarrheal disease may also be involved in non gastrointestinal infections (6). The research of $B$. cereus with regard food has gained significance in the light of its capability to form endospores have heat resistance and capacity to grow and produce toxins in a wide range of foods (28). Bacteriocins are antimicrobial peptides secreted by certain bacterial strains, which are immune to them, to compete by inhibiting the growth of other bacteria present in their environment. Nisin is a bacteriocin of the lantibiotics group, whose use as a food preservative was approved by the European Union (food additive number E234, EEC, 1983) and the Joint Food and Agriculture Organization/World Health Organization (FAO/WHO), and it is currently the most studied and characterized of all the bacteriocins produced by lactic acid bacteria (LAB). For some food the quantity of Nisin added is about 25 ppm (13). Many reports about lantibiotics extensively subclass of bacteriocins, which includes staphylococcin C55 and Nisin A have highly activity against food-borne pathogens (5). However, it was noticed in the recent years that some bacteria have resistance to Nisin $A$ as a result of exposure of cells to high levels of it (17). Staphylococcus auraus found to be established resistance easily to nisin due to spontaneous mutation (16). Meat has exerted is an important component of a healthy. It is importance in human nutrition as well as examines some pejorative beliefs about meat consumption. Rosmarinus officinalis Rosmary is medicinal plant back to the Lamiaceae family. It used in traditional medicine and in food products as a flavoring agent due to its desirable flavor, antioxidant and antimicrobial effects (14,9). Plant volatile oils have antimicrobial activities; however they limited used in foods due to their strong flavor. In the latest years, plant extracts used in foods as antioxidants. The rosemary extract was tested against some food spoilage and foodborne pathogenic microorganisms under various conditions of $\mathrm{pH}$, water activity, and temperature (8). Synthetic antimicrobial preservatives were used for many years in the food industry, but their consumption can lead to intoxications, allergies, cancer ...etc. Thus, the search for natural products as new antimicrobial agents derived from animals, plants and microorganisms used in food industry (14). The canned meat products are widely consumed who give concerns about food poisoning caused by pathogens as well as the potential risk of Nisin A. However, although many studies have shown the effect of preservatives on canned food and its harm to consumers, little attention has been paid to evaluating the risks of resistance of contaminated bacteria in canned foods, including canned meat, against Nisin. Thus, this study was focused on isolating B. cereus from meat sources that deals with human food poisoning. Furthermore, comparison between the activity of Nisin A and rosemary volatile oil as antibacterial and food preservative material in vitro and in vivo.

\section{MATERIALS AND METHODS}

\section{Sampling and culture media}

From some markets in Baghdad city, one hundred canned food samples (Fried meat and Grilled meat) were collected. All samples were cultured on mannitol yolk polymyxin agar (MYP), a medium used for the detection, enumeration and isolation of $B$. cereus in food samples then incubated for $24 \mathrm{~h}$ at $30^{\circ} \mathrm{C}(11)$.

\section{Identification of bacteria using $16 \mathrm{~S} r \mathrm{RNA}$}

The 16S rRNA was amplified using the primers 27F (AGAGTTTGATCTTGGCT CAG) and1492R (TACGGTTACCTTGTT ACGACTT) (29). The PCR tube was contain $12.5 \mu 1$ of GoTag Green Master Mix (Promega, USA), $1 \mu \mathrm{M}$ of each primer and $2 \mathrm{ng} / \mu \mathrm{l}$ of template DNA (Wizard Genomic DNA Purification Kit, Promega), the volume was completed to $25 \mu \mathrm{l}$ with nuclease free water. The PCR reaction was carried out for $5 \mathrm{~min}$ at $95^{\circ} \mathrm{C} ; 30$ cycles of denaturation for $30 \mathrm{sec}$ at $95^{\circ} \mathrm{C}$, annealing for $45 \mathrm{sec}$ at $60^{\circ} \mathrm{C}$, extension for $1 \mathrm{~min}$ at $72^{\circ} \mathrm{C}$ then final extension for $7 \mathrm{~min}$ at $72^{\circ} \mathrm{C}$. The PCR product was separate in $1 \%$ 
agarose gel electrophoresis stained with ethidum bromide and visualized on a UV transilluminator. The amplicons were sending for Sanger sequencing using ABI3730XL, automated DNA sequencer, by Macrogen Corporation, Korea.

Preparation of rosemary volatile oil and Nisin A

The plant collected from Baghdad University campus-College of science, then dried and finely grounded, with $300 \mathrm{~g}$ dry plant powder in $1.5 \mathrm{~L}$ distilled water for $5 \mathrm{~h}$. the volatile oil were extracted by hydro distillation using Clevenger apparatus, and three concentrations 500, 1000 and $2000 \mu \mathrm{g} \backslash \mathrm{ml}$ was prepared with D.W (v/v) and kept at $4^{\circ} \mathrm{C}$ until use $(19,4)$. Nisin A (Sigma Nisaplin, Germany) was prepared by dissolved $100 \mathrm{mg}$ from Nisin A powder in $10 \mathrm{ml} \mathrm{HCl}(0.02 \mathrm{~N})$ to give $10^{4}$ $\mathrm{IU} / \mathrm{ml}$, three concentrations (1300, 650 and $350 \mathrm{IU} \backslash \mathrm{ml}$ ) were prepared. For sterilization, the solutions were passed throughout 0.45 filters then stored at $-20^{\circ} \mathrm{C}(20)$.

Determine the inhibitory volatile oil and Nisin A on B. cereus

Determination the antimicrobial effect of the Rosemary volatile oil and Nisin A on $B$. cereus planktonic cell using well diffusion assay method was applied according to (10). The concentration give highest diameter of inhibition zone has been chosen for further studies.

\section{Determine the activity of rosemary volatile oil and Nisin $A$ as preservative agents}

The fresh meat was obtained from Baghdad market and stored at $-15^{\circ} \mathrm{C}$. Before the experiments, the samples were thawed at room temperature and cut with a sterile scalpel into small pieces $(2.5 \mathrm{~cm}$ widith $\times 3 \mathrm{~cm}$ long $\times 1 \mathrm{~cm}$ high) then washed with sterilized D.W and boiled for $3 \mathrm{~h}$. Finally, the meat pieces were poured into large jars and filled with sterilized D.W then boiled for $30 \mathrm{~min}$ (15). The meat pieces were soaked with effective concentration of Rosemary volatile oil and Nisin A solution $(2000 \mu \mathrm{g} \backslash \mathrm{ml}$ and $350 \mathrm{IU} / \mathrm{ml}$ respectively) for $10 \mathrm{~min}$ at room temperature separately. Nine days, after the bacterial through counting of bacterial colony on nutrient agar then compared to meat without adding Rosemary volatile oil and Nisin A (control) every three days (31).

\section{Toxicity assay and histopathological study}

Three groups of albino male mice were obtained from Al-Nahran central, aged 5-6 weeks and weighing 20-25 g kept in plastic cages in the animal house of Baghdad Research Center, University of Baghdad. Each group consisted of four mice, group 1 (control) was fed with $0.1 \mathrm{ml}$ of physiological solution via mouth oral syringe while group 2 and 3 were fed orally with effective concentration of Rosemary volatile oil and Nisin A for 14 days respectively. For histopathological study, mice were killed using diethyl ether and vivisection to liver and spleen. The organs were kept in formalin before lab investigation. The mice were left for 10 day for adaptation before the experiments beginning.

\section{Statistical analysis}

The results were analyzed using the SPSS IBM version 20. Least significant differences (LSD) test was done to determine the differences between inhibition zone diameters of antimicrobial agent as well as between the colony forming unit count for meat treated with Nisin A, Rosemary volatile oil and control.

\section{RESULTS AND DISCUSSION}

The results showed that from 100 meat samples, and screening as B. cereus the four isolates were identified on MYP medium and confirmed the identification after the amplification of $16 \mathrm{~S} r R N A$ and sequencing the products $(1500 \mathrm{bp})$ as shown in Figure 1 . The gene has better efficiency than its counterpart, $16 S r R N A$ because of faster evolutionary rate which contributes to lesser percentage of gene similarities, even among closely related species and therefore suitable for bacterial species identification (23). The $16 S$ rRNA gene sequences of three PCR amplicons were compared with the GenBank database using BLASTn in NCBI and found high similarity to the sequences of Bacillus cereus ATCC 14579 registered in GenBank with $99 \%$ identity. As shows in Figure 2, in inhibitory zone diameters between Nisin A and Rosemary. The results of different Nisin concentrations showed highly significant differences $(\mathrm{P} \leq 0.01)$. Nisin A inhibitory effects at concentrations 350 and $650 \mathrm{IU} / \mathrm{ml}$ had higher diameter while at 1300 $\mu \mathrm{g} \backslash \mathrm{ml}$ observed lower diameter. The result agreed with (25) study which reported the 
Abed \& et al.

antimicrobial effect of Nisin against $B$. cereus at different concentration during storage. However, the diameter decreased with Nisin A concentration increased may resulting from the bacteria might be resistant to these high concentrations through unknown mechanism which need further study.

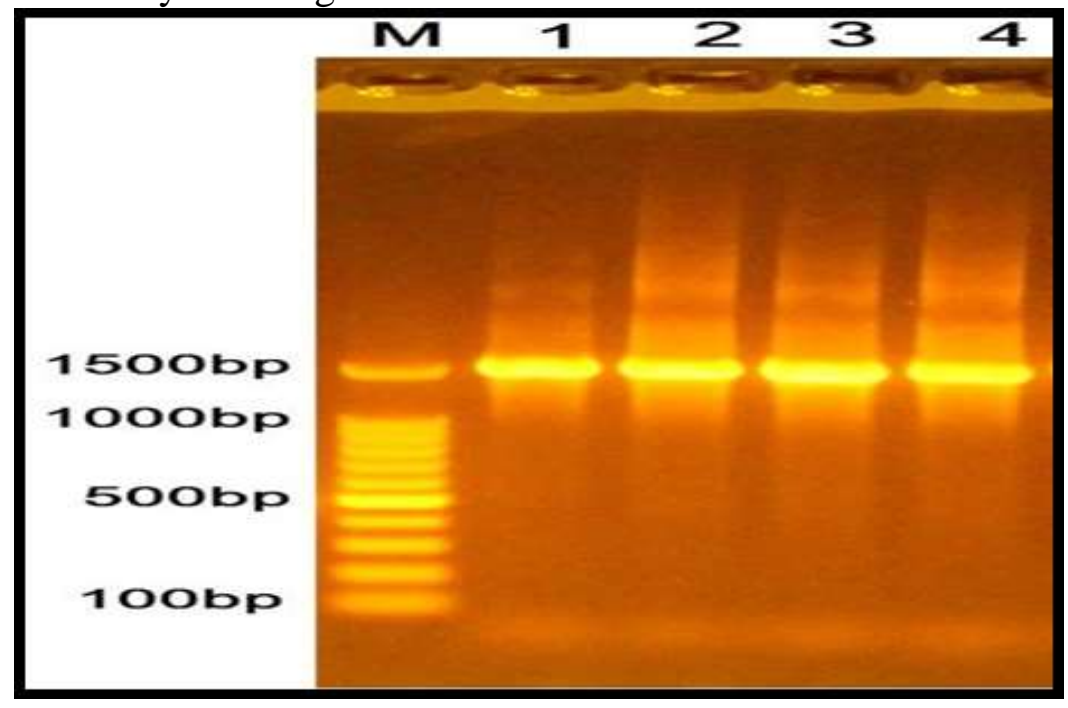

Figure 1. PCR amplicons of the $16 S \mathrm{rRNA}(1500 \mathrm{bp})$ from bacterial genomic DNA stained with ethidium bromide. Lanes 1-4. Unknown bacterial isolates, Lane M. 100 bp DNA ladder. The amplicons was electrophoresis on $1 \%$ agarose (1x TBE buffer) at 5 volt $/ \mathrm{cm} 2$ for $90 \mathrm{~min}$

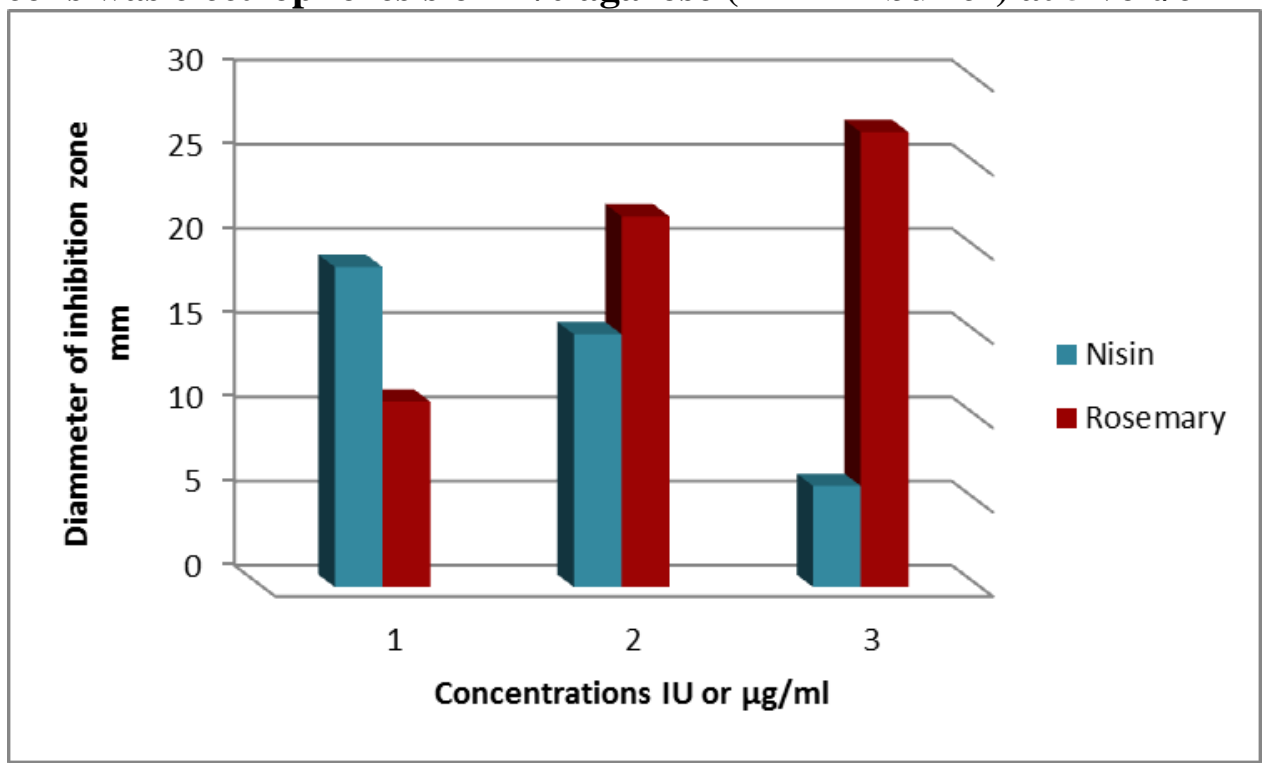

Figure 2. Inhibitory zone diameter of Nisin A concentration range (1-350, 2- 650, 3- 1300 IUlml) and Rosemary volatile oil at different concentrations $(1-500,2-1000,3-2000 \mu \mathrm{g} / \mathrm{ml})$ on B. cereus bacterium

The results of different Rosemary volatile oil concentrations showed highly significant differences $(\mathrm{P} \leq 0.01)$. The concentrations of the volatile oil $(500,1000$ and $2000 \mu \mathrm{g} / \mathrm{ml})$ used against $B$. cereus showed inhibition zone reached to 11,22 and $27 \mathrm{~mm}$ respectively The rosemary extract as an antioxidant of lipids in foods and antimicrobial against foodborne microorganisms such Bacillus spp (1). The volatile oils have strong antibacterial activities against microorganisms due to a high percentage of phenolic secondary metabolites compounds (2,3,8 24). Many extracts were achieved from ginger roots included water extract, effects some microorganisms such as Salmonella typhimurium, E. coli, B. cereus, S. aureus and, Pseudomonas aeruginosa (21). The effect of Nisin A and Rosemary on the growth of bacteria on laboratory canned meat are shows in Figure (3) and Table (1). After counting of bacterial colony on nutrient agar every three days, the samples with Rosemary volatile oil was not showed any CFU colony /g after 9 days of preservation while sample with 
Nisin A and control observed number of colony between 49 and $45 \mathrm{CFU} / \mathrm{g}$ respectively. Moreover, the results in Table 1 show significant differences $(\mathrm{P} \leq 0.05)$ in $\mathrm{CFU}$ count after 9 day of treating the meat with Rosemary volatile oil in contrast to control and Nisin A.

Table 1. Distribution of $B$. cereus plate count for meat samples

\begin{tabular}{|lccccccccc|}
\hline & \multicolumn{4}{c}{ Distribution of bacterial count (CFU/g) } \\
\multicolumn{1}{c}{ Groups } & \multicolumn{3}{c|}{ Diler (3) days } & \multicolumn{3}{c|}{ After (6) days } & \multicolumn{3}{c|}{ Dfter (9) days } \\
& Dilution & Dilution \\
\hline Dilution & $\mathbf{1 0}^{-1}$ & $\mathbf{1 0}^{-2}$ & $\mathbf{1 0}^{-3}$ & $\mathbf{1 0}^{-1}$ & $\mathbf{1 0}^{-2}$ & $\mathbf{1 0}^{-3}$ & $\mathbf{1 0}^{-1}$ & $\mathbf{1 0}^{-2}$ & $\mathbf{1 0}^{-3}$ \\
Control & $\mathbf{2 5}$ & $\mathbf{1 3}$ & $\mathbf{9}$ & $\mathbf{3 7}$ & $\mathbf{2 2}$ & $\mathbf{1 2}$ & $\mathbf{4 9}$ & $\mathbf{3 3}$ & $\mathbf{2 4}$ \\
Rosemary volatile oil & $\mathbf{0}$ & $\mathbf{0}$ & $\mathbf{0}$ & $\mathbf{0}$ & $\mathbf{0}$ & $\mathbf{0}$ & $\mathbf{0}$ & $\mathbf{0}$ & $\mathbf{0}$ \\
Nisin A & $\mathbf{2 0}$ & $\mathbf{1 3}$ & $\mathbf{9}$ & $\mathbf{3 3}$ & $\mathbf{1 7}$ & $\mathbf{1 1}$ & $\mathbf{4 5}$ & $\mathbf{3 0}$ & $\mathbf{1 8}$ \\
\hline
\end{tabular}

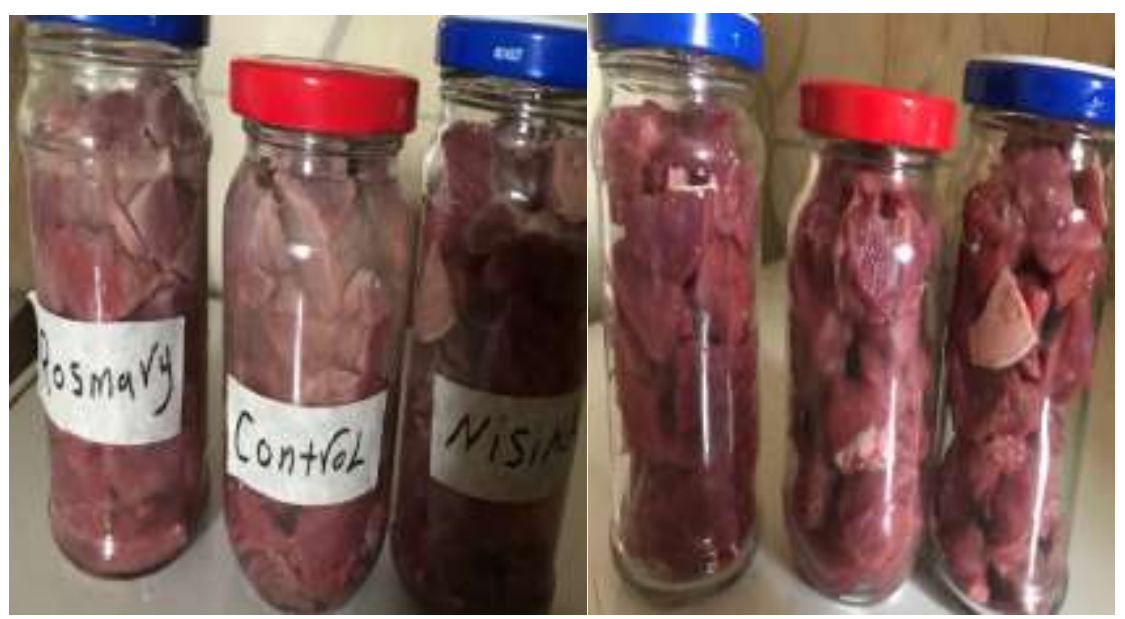

Figure 3. Preparation of Canned Meat with Nisin A and Rosemary volatile oil at concentrations $350 \mathrm{IU} / \mathrm{ml}, 2000 \mu \mathrm{g} \backslash \mathrm{ml}$ respectively and control.

Consistent with this result, the average Aerobic plant counts (APCs) for retail cuts of beef samples in the study of Eisel et al. (12) were approximately $3 \mathrm{CFU} / \mathrm{g}$. Other results shown combination of equal volume of thyme oil with cinnamon oils lead to reduce the count of B. cereus in minced meat $96.09 \%$ (27). Henning et al. (16) reported that Nisin is unstable on meat which activity decreased rapidly over time, especially at room temperature. It has been suggested that Nisin to meat particles and surfaces may cause loss of Nisin activity. There are problems of using Nisin A for preservation of meat due to low solubility, uneven distribution, and instability on the meat of surface. Therefore, Nisin alone may not be enough to prevent spoilage, as the gram-negative bacteria and Nisin resistance such as lactic acid bacteria are often associated with meat spoilage. The results of toxicity assay showed no death in experimental animal for all groups of study. In vivo results when vivisection the liver and spleen then preparing the histopathological sections, they were found no harmful effect after using of $350 \mathrm{IU} / \mathrm{ml}$ $(17.5 \mathrm{mg} / \mathrm{kg}$ ) of Nisin for 14 days (Figure 4). In contrast to control, $2000 \mu \mathrm{g} / \mathrm{ml}(10 \mathrm{mg} / \mathrm{kg})$ Rosemary volatile oil was induced more extensive organ damages such as multifocal liver cell degeneration, necrosis and hemorrhage and multifocal increase of tangible body macrophages in spleen (Figure $5)$. A common plant grown in many parts of the world ( $R$. officinalis), it is used (medicine, as an antispasmodic) (18). On the study the effect of the aqueous extract on overdose consumption of aspartame showed of rosemary extract these defects in the histological architecture of the kidney (26) Marja et al., (22) who found that plants extracts and different types of chromosomal aberrations. 

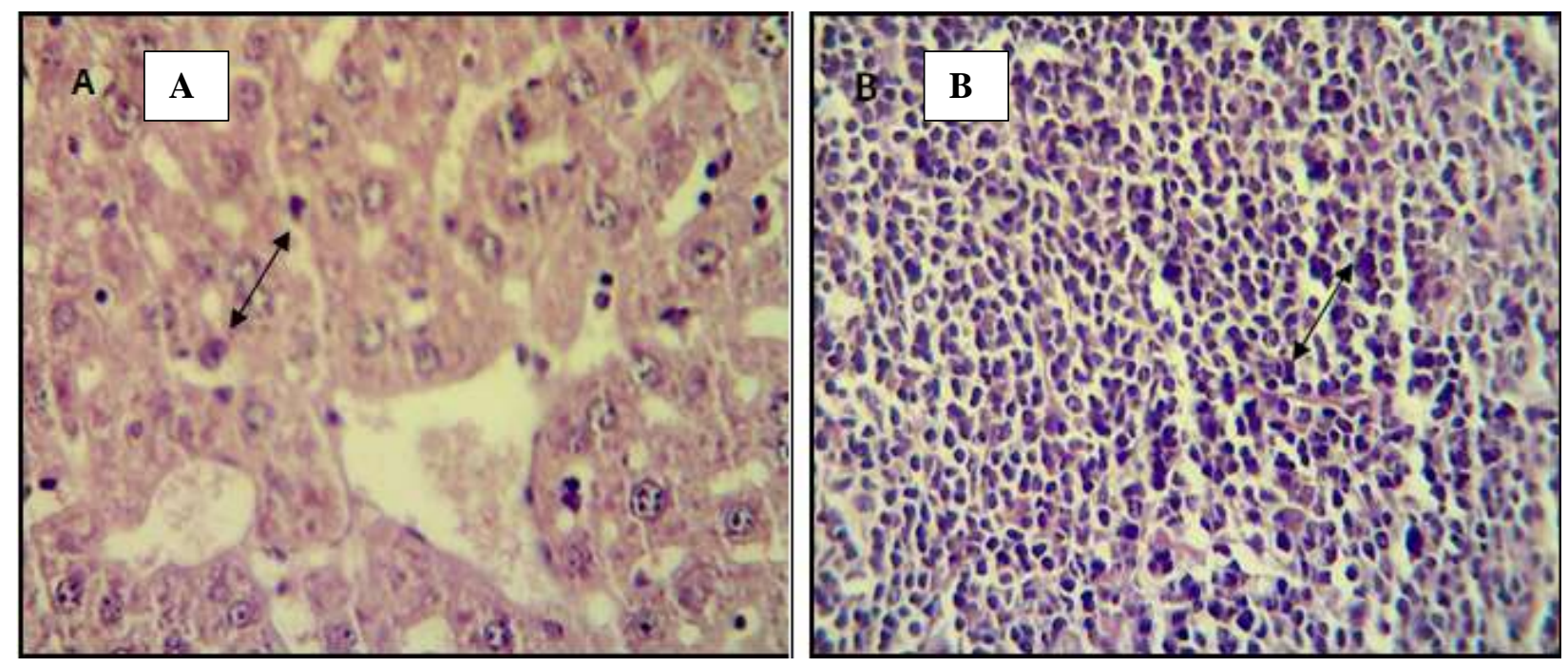

Figure 4. Histopathological section the liver (A) and spleen (B) after treated with Rosemary volatile oil $2000 \mu \mathrm{g} \backslash \mathrm{ml}$. (A): showed proliferation of kupffer cells with few neutrophils in mild dilated sinusoids. (B): showed moderate proliferation of lymphocytes in periarteriolar sheath. (H and E stain 400X).
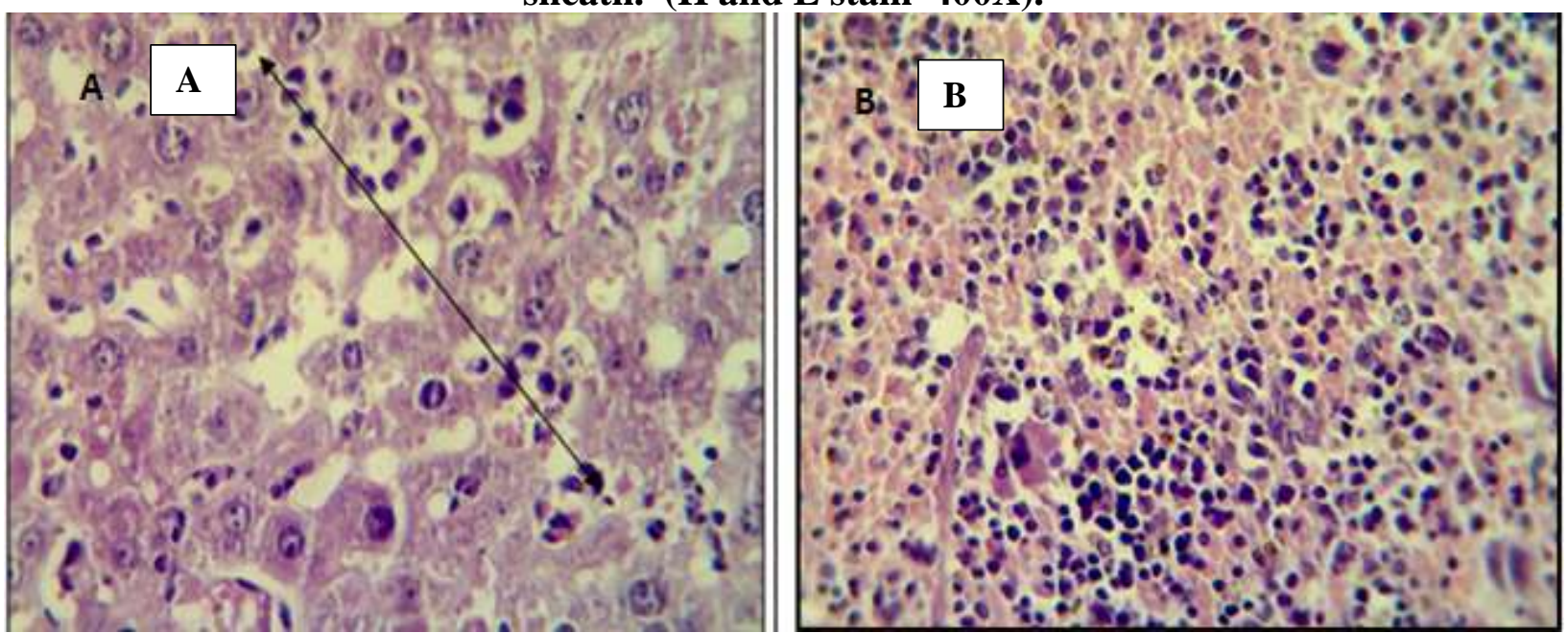

Figure 5. Histopathological section of the liver (A) and spleen (B) after treated with Nicin A $350 \mathrm{IU} / \mathrm{ml}$. (A): showed neutrophils aggregated in dilated congested sinusoids and necrosis of hepatocytes. (B) showed neutrophils infiltration of congested red pulp with depletion of white pulp (H and E stain 400X).

In the light of our results, rosemary volatile oil has proven to be very effective as a preservative substance, as it has shown great effectiveness against the bacteria $B$. cereus isolated from meat compare with using Nisin $A$ at different concentrations which need further studies as preservative agent for meat products.

\section{REFERENCES}

1. Abdul Husain Z. M. and L. K Jawad. 2019. Effect of magnetic field on the growth, multiplication and concentration of the volatile oil of Rosemary officinalis In Vitro. Iraqi, J. Agri. Sci. 9:50 (4): 982- 989

2. Abdulhasan, G. A. 2015. The biological effect of Rosmarinus officinelis L. volatile oil on biofilm formation and some fimbrial genes (fimH-1 and mrkD) of Klebseilla pneumonia. Iraqi J. Sci, 56(3C), 2553-2560

3. Abdulhasan, G. A., S. K. Alzubaidy, and I. J. Abed 2016. Effect of sub-inhibitory and inhibitory concentrations of some antibiotics and rosemary volatile oil (Rosmarinus officinalis L.) on biofilm formation of Klebsiella pneumoniae. World J Exp Biosci, 4, 130-135.

4. Al-Dorkzali, A E. 2005. Effect of Nitrogen and Phosphate Fertilization in the Vegetative Growth of Rosmarinus officinalis L. M.Sc. Thesis. Collage of Agriculture, University of Baghdad. pp:65 
5. Anita, T. and A. Swaid 2015. Bacillus cereus food poisoning: international and Indian perspective, J. Food. Sci. Technol. 52(5):2500-2511

6. Ankolekar, C., T. Rahmati and R.G. Labbe 2009. Detection of toxigenic Bacillus cereus and Bacillus thuringiensis spores in U.S. rice. Int. J. Food. Microbiol. 128:460-466

7. Arii K., M. Kawada-Matsu, Y. Oogai, K.Noguchi and H. Komatsuzawa 2018. Single mutations in BraRS confer high resistance against nisin A in Staphylococcus aureus, Microbiologyopen. 11:791

8. Asmaa, S. I., N. M. Salih, and B.A. Alani 2007. Studying the effect of ginger roots extracts on microorganism. Iraqi, J. Agri. Sci. 38 (3): 43-48

9. Azizkhani, M. and F. Tooryan, 2015. Antioxidant and antimicrobial activities of rosemary extract, mint extract and a mixture of tocopherols in beef sausage during storage at 4C. J. Food. Saf., 35: 128-136

10. Balouiri M, M. Sadiki and S. K. Ibnsouda 2016. Methods for in vitro evaluating antimicrobial activity: A review. J. Pharm. Anal.. 6( 2): 71-79

11. Carlin, F., M. H. Guinebretiere, C. Choma, R. Pasqualini, A. Braconnier and C. Nguyen 2000. Spore-forming bacteria in commercial cooked, pasteurised and chilled vegetable pure'es. Food Microbiol. 2:153-165

12. Eisel W. G., R. H. Lintonand and P. M. Muriana. 1997. A survey of microbial levels for incoming raw beef, environmental sources, and ground beef in a red meat processing plant. Food Microbiol. 14, 273-282

13. Fernández-Pérez R, Y .Sáenz, B. RojoBezares, M. Zarazaga, J.M. Rodríguez, C. Torres, C. Tenorio and F. Ruiz-Larrea 2018. Production and antimicrobial activity of Nisin under enological conditions. Front Microbiol. 5(9):1918.

14. Field D., K. Daly, P.M. O'Connor, P.D.Cotter, C. Hill and R.P. Ross 2015. Efficacies of nisin A and nisin V semipurified preparations alone and in combination with plant volatile oils for controlling Listeria monocytogenes. Appl. Environ. Microbiol. 81, 2762-2769

15. Hampikyan H. and M. Ugur 2007. The effect of nisin on L. monocytogenes in Turkish fermented sausages (sucuks). Meat Sci. 76: 327-332

16. Henning, S., R. Metz, and W. P. Hammes. 1986. Studies on the mode of action of nisin. Int. J. Food Microbiol. 3:121-134

17. Hiron A, M. Falord, J. Valle, M. Debarbouille and T. Msadek 2011. Bacitracin and nisin resistance in Staphylococcus aureus: a novel pathway involving the BraS/BraR twocomponent system (SA2417/SA2418) and both the $\mathrm{BraD} / \mathrm{BraE}$ and $\mathrm{VraD} / \mathrm{VraE} \mathrm{ABC}$ transporters. Mol Microbiol 81:602-622

18. Hozayen W G. 2014. Potential protective effects of Rosemary extract, against aspartame toxicity in male rats. J. Inter. Acad. Reser. Multidisc.; 2(6): 111-125

19. Jamshidi R., Z. Afzali and D. Afzali 2009. Chemical composition of hydrodistillation volatile oil of rosemary in different origins in Iran and comparison with other countries. American-Eurasian J. Agric. \& Environ. Sci. 5 (1): 78-81

20. Papagianni M., N. Avramidis, G. Filioussis, D. Dasiou, and I. Ambrosiadis 2006. Determination of bacteriocin activity with bioassays carried out on solid and liquid substrates: assessing the factor indicator microorganism. Microbial Cell Factories , 5(1): 30 .

21. Maeh R. K., A.I. Jaaffar and K.F. ALazawi 2019. Preparation of Juniperus extract and detection of its antimicrobial and antioxidant activity. Iraqi, J. Agri. Sci. 50(4):1153-1161

22. Marja P. K., I. H. Anu, J. V. Heikki, R. Jussi-Pekka, P. Kalevi, S.K. Tytti and H. Marina 1999. Antioxidant activity of plant extracts containing phenolic compounds J Agr Food Chem. 47 (10): 3954-396

23. Mörlein J., L. Meier-Dinkel, J. Gertheiss, W. Schnäckel and D. Mörlein 2019. Sustainable use of tainted boar meat: Blending is a strategy for processed products. Meat Sci. 152:65-72

24. Najem A. M. and J. A. Ibrahim 2017. Potential use of Rosemary (Rosmarinus officinalis L.) volatile oil as anti-bacterial and anti-algal. J Pharm Biol Sci, 12(2), 68-71

25. Pereira P. and A. Vicente 2013. Meat nutritional composition and nutritive role in the human diet. Meat Sci; 93:586-92 
26. Sahu B.D., K.K.R. Rentam U.K., Putcha M. Kuncha, G.M.N. Vegi and R. Sistia, 2011. Carnosic acid attenuates renal injury in an experimental model of rat cisplatin-induced nephrotoxicity. Food Chem Toxicol. 49: 3090-3097

27. Salem A. M., E. F. Mohamed and E.M. Selim 2018. Antimicrobial effect of some natural oils on Bacillus cereus in minced beef. Benha Veterinary Medical Journal. 34 (2):149156

28. Silva C. C. G., S. P. M Silva and S. C. Ribeiro 2018. Application of bacteriocins and protective cultures in dairy food preservation. Front. Microbiol. 9:594.
29. Srinivasan R., U. Karaoz, M. Volegova, J. MacKichan, M. Kato-Maeda, S. Miller, R. Nadarajan, E. Brodie and S. Lynch 2015. Use of $16 S$ rRNA gene for identification of a broad range of clinically relevant bacterial pathogens. PLoS One.; 10(2): e0117617

30. Tewari A., S. P. Singh, and R. Singh 2015. Incidence and enterotoxigenic profile of Bacillus cereus in meat and meat products of Uttarakhand, India. J. Food Sci. Technol. 52, 1796-1801

31. Zullo AM, C. Chen and K. Lewis 2015. A new antibiotic kills pathogens without detectable resistance. Nature. 517: 45. 